\title{
METABOLIC EFFECTS OF EXERCISE \\ IN THE GOLDEN FISH Salminus maxillosus "DOURADO" (VALENCIENNES, 1849)
}

\author{
MORAES, G., ${ }^{1}$ CHOUDHURI, J. V., ${ }^{1}$ SOUZA, R. H. S. ${ }^{2}$ and NETO, C. S. ${ }^{1}$ \\ ${ }^{1}$ Departamento de Genética e Evolução, Universidade Federal de São Carlos, Rod. Washington Luís, \\ km 235, CEP 13565-905, São Carlos, SP, Brazil \\ ${ }^{2}$ Centro de Pesquisa em Agricultura CEPTA/IBAMA, Rod. Brigadeiro Faria Lima, s/n, \\ km 6.5, C.P. 64, CEP13630-000, Pirassununga, SP, Brazil \\ Correspondence to: Gilberto Moraes, Departamento de Genética e Evolução, Universidade Federal de São Carlos, \\ Rod. Washington Luís, km 235, CEP 13565-905, São Carlos, SP, Brazil, e-mail: gil@ power.ufscar.br \\ Received May 20, 2002 - Accepted August 14, 2003 - Distributed August 31, 2004
}

(With 1 figure)

\begin{abstract}
Strenuous exercise in fish is usually a consequence of migration, reproduction, and spawning. Varying among fishes, this kind of stress is associated with blood glucose and lactate increase, in relation to which two major groups are distinguishable: the "lactate releasers" and "non-lactate releasers". Unlike strenuous exercise, sustained swimming imposes a variety of effort that results in distinct kinetic types of blood lactate and glucose. Compared to Platichthys stellatus and Oncorhynchus mikyiss, blood lactate of Salminus maxillosus (dourado) was lower after exercise, whereas recovery time was greater. Great demands were made of white muscle, and dourado is not a lactate releaser. Two different metabolic tendencies were observed in sustained and intense swimming. Gluconeogenesis was observed during recovery, as well as the alanine cycle which recomposes the lactate tissue pattern. Full recovery after intensive exertion required more than 24 hours.
\end{abstract}

Key words: fish exercise, lactate kinetics, chasing, sustained swimming, Salminus maxillosus, metabolic adaptation.

\section{RESUMO}

\section{Efeitos metabólicos do exercício em dourados Salminus maxilosus (Valenciennes, 1849)}

Exercício intenso em peixes normalmente é conseqüência de migração, reprodução e desova. Esse tipo de esforço está associado ao aumento de glicose sangüínea e de lactato, o qual varia entre as diferentes espécies de peixes. Dois grupos são conhecidos, os "liberadores" e os "não liberadores" de lactato. Diferentemente do exercício intenso, o exercício contínuo impõe certo esforço que resulta em distintos tipos de cinética de lactato e glicose. A concentração de lactato plasmático em Salminus maxillosus é menor após o exercício quando comparada à Platichthys stellatus e Oncorhynchus mikyiss, mas o tempo de recuperação é maior. A musculatura branca é particularmente requisitada e o dourado apresenta-se como um "não liberador" de lactato. Duas tendências metabólicas distintas foram observadas para o exercício contínuo e intensivo. A gliconeogênese, que foi observada durante a recuperação, e o ciclo da alanina, que recompôs o padrão tissular de lactato. O período de completa recuperação do exercício intenso foi maior que 24 horas.

Palavras-chave: exercício em peixes, cinética de lactato, Salminus maxillosus, natação contínua, natação intensiva, adaptação metabólica. 


\section{INTRODUCTION}

Reproduction, spawning, and early developmental stages are often associated with migration for many tropical fishes. Long distances traversed in rivers, and rapids and falls encountered along the way result in various swimming speeds. The strenuous exercise required raises blood glucose and lactate (Wydoski et al., 1976; Haux et al., 1985; Schwalme \& Mackay, 1985a, 1985b). Better understanding of the role of lactate and glucose in fishes as a result of intensive exercise demands kinetic studies. A lactate and/or glucose accumulation followed by depletion of stored glycogen in the liver is very distinct among fishes. The blood lactate of channel catfish (Ictalurus punctatus) rises after five minutes of exercise but the maximum values are only reached ten minutes after swimming (Cameron \& Cech, 1990). Fast recovery from exercise (four hours), the glucose concentration rise, and the gluconeogenesis increase in this species are due to its great oxidative potential. In contrast, blood lactate of salmonids after intensive swimming increases by 8-10 times the values presented by that of the channel catfish (Milligan \& Girard, 1993). This concentration, representing $10 \%$ to $20 \%$ of total body lactate, ranks this species among the "lactate-releasers" (Wood \& Perry, 1985) in contrast to the "non-releasers", like the plaice Pleuronectes platessa L. (Wardle, 1978).

Following lactate mobilization, a glucose concentration rise is also observed in some species after exercise (Haux et al., 1985; Schwalme \& Mackay, 1985a, 1985b) and recovery is observed after 24 hours, as reported for the yellow perch Perca flavescens (Schwalme \& Mackay, 1991). However, after strenuous exercise, glucose concentration keeps increasing for eight hours. Some mechanisms have been proposed to explain this fact: 1) glycogenolysis; 2) slow disappearance of lactate via the Cori cycle; 3 ) gluconeogenesis from glycerol or amino acids; and 4) preferential oxidation of lactate, which inhibits glucose catabolism.

The freshwater teleost fish Salminus maxillosus "dourado" lives in warm rivers of South America. It migrates long distances during the reproductive life-cycle in well-aerated waters, crossing rapids or simply swimming towards the headwaters. The species is carnivorous, frequently having been observed during migration taking preys in bursts. We assumed that sustained swimming during the cruise is the resting period in the journey. Consi- dering that the dourado usually lives in lotic, wellaerated waters we also expected low tolerance to lactate. This study presents a metabolic comparison between adult dourado fish submitted to both sustained swimming and the intensive exercise imposed by the chase.

\section{MATERIAL AND METHODS}

\section{Fish collection and maintenance}

Adult fish Salminus maxillosus "dourado" were collected from Cachoeira de Emas, a rapid in MogiGuaçu River, Pirassununga (21 ${ }^{\circ} 58^{\prime}$ 'S $\left.-47^{\circ} 26^{\prime} \mathrm{W}\right)$, SP, Brazil and transported to the aquaculture facilities of the Aquaculture Research Center CEPTA/IBAMA in Pirassununga, SP. The entire procedure was performed in January-February following two separate procedures. All fish (41, weighing $1.7 \pm 0.7 \mathrm{~kg}$ (means \pm SD)) used were kept unfed in 5,000 L tanks seven days prior to the experiments. The tanks were supplied with aerated water (7.5 ppm of oxygen) pumped from the Mogi-Guaçu River and the quality of which was identical for all experiments. Water temperature was constant $\left(926 \pm 1^{\circ} \mathrm{C}\right)$ and $\mathrm{pH}$ was 6.5 .

\section{Experiment design}

Two designs were used to evaluate metabolic changes in $S$. maxillosus submitted to exercise: sustained swimming for $15 \mathrm{~min}$ in EXPERIMENT I, and chase followed by recovery in EXPERIMENT II.

\section{Experiment I}

Eleven dourados were anaesthetized by dipping them into 0.27 g.L $\mathrm{L}^{-1} \mathrm{MS} 222$ solution following which a cannula was fitted into the dorsal aorta (Waring et al., 1992). After surgery, the fish were transferred for $48 \mathrm{~h}$ of rest and recovery in individual plastic cages divided among 1,000 L fiberglass tanks with black covers. Fopllowing that, preliminary blood samples $(700 \mu 1)$ were taken (pre-control). The tanks were gradually exposed to natural light, and two hours later the fish were submitted to pumped water running at $0.5 \mathrm{~cm}$. sec $\mathrm{se}^{-1}$. At the beginning of the swimming period, a second blood sample was taken (control) and subsequent samples were taken at 3, 6, 9, 12, and 15 minutes. Blood was collected in $1.0 \mathrm{ml}$ syringes and transferred to heparinized $2.0 \mathrm{ml}$ polypropylene tubes. The withdrawn blood volume was replaced with an equivalent amount of $0.8 \% \mathrm{NaCl}$ solution and the cannula dead space was refilled with $0.8 \%$ $\mathrm{NaCl}$ solution containing heparin $20 \mathrm{U} \mathrm{ml}^{-1}$. Samples 
of whole blood were used for hematocrit and the remainder was centrifuged at $9,000 \mathrm{~g}$ for 5 minutes. The supernatant was split into plasma aliquots and stored at $-20^{\circ} \mathrm{C}$ for posterior biochemical analysis.

\section{Experiment II}

Twenty-four fish were placed in four 2,000 L plastic containers (I, II, III, IV), kept in aerated water at $26 \pm 1^{\circ} \mathrm{C}$ under shadow-proof netting covers, and left undisturbed for 24 hours. Six fish from container I were kept untouched and used as a reference. These control fish were sampled immediately after the conclusion of the chase experiment as described below. Six fish from container II were stressed by chase and some burst swimming imposed by nudging them in the tail. This part of the experiment was done keeping the observer hidden to protect the fish from another source of stress. After $14 \pm 1 \mathrm{~min}$, the completely exhausted fish were quickly collected. Blood was drawn from the caudal vein into heparinized syringes. The fish were killed by pinching the neural cord, and the liver and red and white muscle were excised and immediately frozen in liquid nitrogen for posterior biochemical analysis.

Six fish from container III plus six from container IV were stressed as previously described for container II. After that, they were allowed to recover for 6 and $24 \mathrm{~h}$ respectively. They were then sampled for blood and tissue, as just described.

\section{Tissue extract}

Liver and muscles were completely homogenized in 10 volumes of $6 \mathrm{~N}$ perchloric acid (PCA) under ice bath by two $30 \mathrm{sec}$. strokes. The acid homogenate was centrifuged at $10,000 \mathrm{~g}$ and the supernatant was used for glucose, lactate, and inorganic phosphorous determination (Pi). This acid extract was neutralized by adding a suitable volume of $6 \mathrm{~N} \mathrm{KOH}$ and quickly centrifuged for pyruvate determination in the supernatant.

Liver and muscle were homogenized, as described before, in 5 volumes of cold distilled water. The homogenate was centrifuged for $3 \mathrm{~min}$ at 3,000 $\mathrm{g}$ and 1 volume of the supernatant was added with equal volumes of $0.3 \mathrm{~N} \mathrm{Ba}(\mathrm{OH})_{2}$ and $5 \% \mathrm{ZnSO}_{4}$. After centrifuging at 3,000 g for $3 \mathrm{~min}$, the supernatant was used for amino acid determination.

\section{Metabolite determination}

Tissues and plasma extracts were used for colorimetric determination of metabolites. Glucose was estimated by phenol-sulfuric acid (DuBois et al., 1956); lactate was estimated by p. hydroxibiphenilsulfuric acid (Harrower \& Brown, 1972); Pi was estimated by ammonium molibdate-malaquite green (Findlay et al., 1989). Pyruvate was estimated by dinitrophenil hydrazine- $\mathrm{NaOH}(\mathrm{Lu}, 1939)$ and amino acid were estimated by nynhidrine (Copley, 1941).

\section{Glycogen determination}

Tissue glycogen was determined after ethanol isolation followed by acid hydrolysis (Bidinotto et al., 1997). Liver and muscles were completely homogenized in 10 volumes of $6 \mathrm{~N} \mathrm{KOH}$, in a boilingwater bath for 3 minutes. After total dissolution, 0.1 $\mathrm{ml}$ of alkaline extract was transferred to $3.0 \mathrm{ml}$ of ethanol, and $0.1 \mathrm{ml}$ of $10 \% \mathrm{~K}_{2} \mathrm{SO}_{4}$ was added to improve glycogen precipitation. The pellet was resuspended in $3.0 \mathrm{ml}$ of distilled water, and the proper glucose aliquot was determined by the hydrolytic method of DuBois (1956).

\section{Chemicals}

All chemicals were analytical grade and purchased from Sigma Chemical Co. or Merck. The MS222 was from Sandoz.

\section{Statistics}

Tests for significance were performed using ANOVA with means comparisons by Tukey's Test and significance level set at $p<0.05$. Pearson's correlation coefficient was used for some parameters; critical values for (r) were set at $95 \%$.

\section{RESULTS}

Sustained swimming induced substantial changes in the blood metabolite concentration of the dourado (Fig. 1). Plasma lactate concentration rose significantly from basal value of 2.0 (resting fish) to $3.3 \mu \mathrm{mol} . \mathrm{ml}^{-1}$. Glucose and Pi showed the same trend. Glucose initial values of 15.0 reached 17.6 $\mu$ mol.ml ${ }^{-1}$ and Pi changed from 2.0 for the control to $10 \mu \mathrm{mol} . \mathrm{ml}^{-1}$ after $15 \mathrm{~min}$ of swimming. After two hours of exercise, lactate and glucose declined to basal concentration, and inorganic phosphate declined 50 percent. Haematocrit was kept constant (37.4\%) throughout the exercise period.

Plasma glucose increased after chase, remaining high even after 24 hours of recovery, while an opposite result was observed for pyruvate (Table 1). Plasma lactate remained high after six hours of 
chase but returned to basal levels after 24 hours. The plasma level of free phosphate was enhanced during the chase but restored during the recovery period. An opposite profile was observed for glucose and pyruvate. The liver lactate and Pi trends were the same as those observed for plasma, while amino acids increased during recovery. White muscle glycogen and glucose were unchanged during the chase. Pyruvate and amino acids decreased after six hours of recovery. After chase, the level of lactate was enhanced, followed by that of free phosphate. Glycogen and glucose of red muscle, as well as that of white muscle, were constant during the chase. Pyruvate decreased after six hours of recovery. Lactate rose during the chase, remaining high even after 24 hours of recovery. No changes were observed in amino acids from the red muscle, and the free phosphate enhanced during the chase returned to basal levels following recovery. Haematocrit increased from $37.6 \%$ to $40.5 \%$ after chase, returning to normal levels after 24 hours.

\section{DISCUSSION}

A gap exists in information on most groups of fishes regarding the physiology and biochemistry of exercise. Rainbow trout is the most studied fish and, consequently, that about which most is known in terms of exercise physiology, including its metabolic response to sustained swimming. Although the dourado shows a response similar to that of Oncorhynchus mikyiss, some differences must be pointed out. Blood lactate of dourado during either sustained or strenuous exercise falls to lower values than it does for rainbow trout. Compared to both starry flounder (Platichthys stellatus) and rainbow trout, recovery time for dourado almost doubles. These results may reflect some differences in structural and/or metabolic preferences.

During intensive exercise, great demands are placed on white muscle which comprises the greatest portion of fish tissue in fishes and enables high work output in short bursts (Wells et al., 1986). Intensive swimming is primarily powered by white muscle fibers and maintained by anaerobic metabolism leading to acid metabolite production. Lactate is the end product of muscle anaerobic metabolism, and species such as Perca flavescens (Schwalme \& Mackay, 1991) show high concentrations of this metabolite, which explains why salmonids are termed "lactate releasers" (Wood \& Perry, 1985). We are reporting on the metabolic response of dourado submitted to exercise according to two different procedures: sustained swimming and chase. Because of the non-dissociated aspect of exercise and "fright" in the chase procedure, sustained swimming was imposed until the fish were no longer able to maintain themselves stationary. However, in spite of significant metabolic differences between the processes, we cannot consider them definitive. However, the blood lactate observed during swimming against water current suggests that dourado is not a lactate releaser, in spite of the high values reached during the chase.

Inorganic phosphate, although not a gauge specifically reflecting any metabolic situation, perfectly expresses energy level changes. In addition, it may reflect ATP hydrolysis, the immediate source of energy tapped by the most endergonic process in the cell (Hochachka, 1985). Transition from rest to exercise leads to major ATP recycling. It has been reported that anaerobic metabolism contributes with almost $75 \%$ of ATP for skeletal muscle demands (Hochachka, 1985). As for exercise in dourado, it showed two different trends. Sustained swimming resulted in blood Pi increase even after two hours, whereas glucose and lactate levels were recovered. However, exhaustive exercise resulted in liver $\mathrm{Pi}$ decrease within the same period of time post-chase. All tissues studied showed the same trend. This should reflect some over-synthesis of phosphate compounds, like phosphagens, in order to restore energetic substances. In spite of existing hypotheses, the inorganic phosphate profile convincingly indicates that 24 hours was not enough for $S$. maxillosus to recover from strenuous exercise.

Liver amino acid concentration remained high after 24 hours of strenuous exercise. With respect to glycogen bulk enhancement, gluconeogenesis during recovery can be supposed. This feat, associated with amino acid and pyruvate decrease in white muscle and showing the exact same trend, suggests that the alanine cycle recomposes the tissue lactate pattern in dourado. Red and white muscle have the same profile for amino acids and pyruvate. However, red muscle lactate, like that in the liver, remained high even after 24 hours of chase. This metabolic behavior, besides the Pi profile, provides more evidence that 24 hours was not enough for full recovery from the chase in dourado. Moreover, 
this profile suggests that lactate uptake from the blood, whether due to metabolic heart demand or to liver anabolic conversion, also takes part in the lactate kinetics of dourado.

The dourado, like the rainbow trout, exhibits some impressive physical feats: swimming upstream against rapids and strong currents and jumping up waterfalls during reproductive migration (Godoy, 1987). From many points of view, this qualifies it as a potential model of a tropical freshwater fish in the study of exercise. Other studies on metabolism of dourado under exercise are being compared to those for various warm water fish. Together they point to similar metabolic response.

TABLE 1

Metabolic profile of Salminus maxillosus submitted to exhaustive chase.

\begin{tabular}{|c|c|c|c|c|c|c|c|c|}
\hline \multirow{2}{*}{$\begin{array}{l}\text { Compartment/ } \\
\text { Metabolite }\end{array}$} & \multicolumn{8}{|c|}{ Physiological condition } \\
\hline & \multicolumn{2}{|c|}{ Control } & \multicolumn{2}{|c|}{ Chase } & \multicolumn{2}{|c|}{ Recovery-6 h } & \multicolumn{2}{|c|}{ Recovery-24 h } \\
\hline \multicolumn{9}{|l|}{ Plasma/ } \\
\hline Glu & 15.5 & $(1.0)$ & 19.5 & $(1.0) \uparrow$ & 20.1 & $(1.2) \uparrow$ & 18.8 & $(1.1) \uparrow$ \\
\hline Pyr & 0.53 & $(0.04)$ & 0.39 & $(0.02) \downarrow$ & 0.28 & $(0.01) \downarrow$ & 0.25 & $(0.01) \downarrow$ \\
\hline Lac & 1.99 & $(0.1)$ & 9.00 & $(0.8) \uparrow$ & 9.10 & $(0.7) \uparrow$ & 2.01 & $(0.1)$ \\
\hline $\mathbf{P i}$ & 1.01 & $(0.09)$ & 4.91 & $(0.20) \uparrow$ & 0.55 & $(0.05) \downarrow$ & 0.62 & $(0.05) \downarrow$ \\
\hline \multicolumn{9}{|l|}{ LIVER/ } \\
\hline Glyc & 140 & (12) & 63 & $(5) \downarrow$ & 145 & (14) & 175 & (20) \\
\hline Glu & 70 & (5) & 200 & (14) $\uparrow$ & 80 & (7) & 83 & (6) \\
\hline Pyr & 1.00 & $(0.08)$ & 1.38 & $(0.08) \uparrow$ & 0.98 & $(0.05)$ & 0.81 & $(0.04) \downarrow$ \\
\hline Lac & 3.5 & $(0.2)$ & 6.4 & $(0.4) \uparrow$ & 5.1 & $(0.4) \uparrow$ & 4.8 & $(0.4) \uparrow$ \\
\hline Aa & 8.9 & $(0.7)$ & 8.9 & $(0.6)$ & 12.9 & $(0.9) \uparrow$ & 13.0 & $(1.0) \uparrow$ \\
\hline $\mathbf{P i}$ & 23 & $(1.8)$ & 40 & $(2.1) \uparrow$ & 19 & $(0.1)$ & 14 & $(0.1) \downarrow$ \\
\hline \multicolumn{9}{|l|}{ WHITE MUSCLE/ } \\
\hline Glyc & 7.2 & $(0.8)$ & 7.2 & $(0.6)$ & 7.0 & $(0.6)$ & 7.4 & $(0.7)$ \\
\hline Glu & 20.5 & (1.1) & 20.5 & $(1.2)$ & 18.1 & (1.1) & 16.2 & $(1.2)$ \\
\hline Pyr & 0.91 & $(0.07)$ & 0.90 & $(0.07)$ & 0.48 & $(0.02) \downarrow$ & 0.89 & $(0.06)$ \\
\hline Lac & 11.9 & $(1.0)$ & 18.1 & $(1.1) \uparrow$ & 10.8 & $(1.0)$ & 11.9 & $(1.0)$ \\
\hline Aa & 2.51 & $(0.2)$ & 2.51 & $(0.2)$ & 1.75 & $(0.1) \downarrow$ & 2.32 & $(0.1)$ \\
\hline $\mathbf{P i}$ & 30.1 & $(2.2)$ & 59.8 & $(3.1) \uparrow$ & 29.8 & $(3.2)$ & 25.3 & $(1.8)$ \\
\hline \multicolumn{9}{|l|}{ RED MUSCLE/ } \\
\hline Glyc & 10.2 & $(1.1)$ & 10.2 & $(1.2)$ & 9.5 & $(1.0)$ & 10.2 & $(1.1)$ \\
\hline Glu & 23.8 & $(2.1)$ & 23.8 & $(2.2)$ & 24.2 & $(2.2)$ & 23.9 & $(2.1)$ \\
\hline Pyr & 0.95 & $(0.07)$ & 0.96 & $(0.06)$ & 0.62 & $(0.04) \downarrow$ & 0.82 & $(0.07)$ \\
\hline Lac & 2.35 & $(0.01)$ & 3.40 & $(0.02) \uparrow$ & 3.30 & $(0.02) \uparrow$ & 2.72 & $(0.02) \uparrow$ \\
\hline Aa & 4.2 & $(0.02)$ & 4.2 & $(0.04)$ & 3.6 & $(0.02)$ & 4.4 & $(0.03)$ \\
\hline $\mathbf{P i}$ & 28 & $(1.5)$ & 38 & $(1.8) \uparrow$ & 24 & $(1.2)$ & 25 & $(1.1)$ \\
\hline
\end{tabular}

Metabolite concentration \pm (S.D.) of $S$. maxillosus submitted to chase, and recovering for 6 and 24 h. The values are expressed as glyc (glycogen) in $\mu \mathrm{mol}$ of glycosil-glucose per mg of wet tissue; glu (glucose), lac (lactate), pyr (pyruvate), aa (amino acids) and Pi (inorganic phosphate) in $\mu$ mol per mg of wet tissue or per ml of plasma. The arrows $(\uparrow)$ and $(\downarrow)$ means respectively higher and lower values compared to the control at the significance level of $\mathrm{p}<0.05$. 


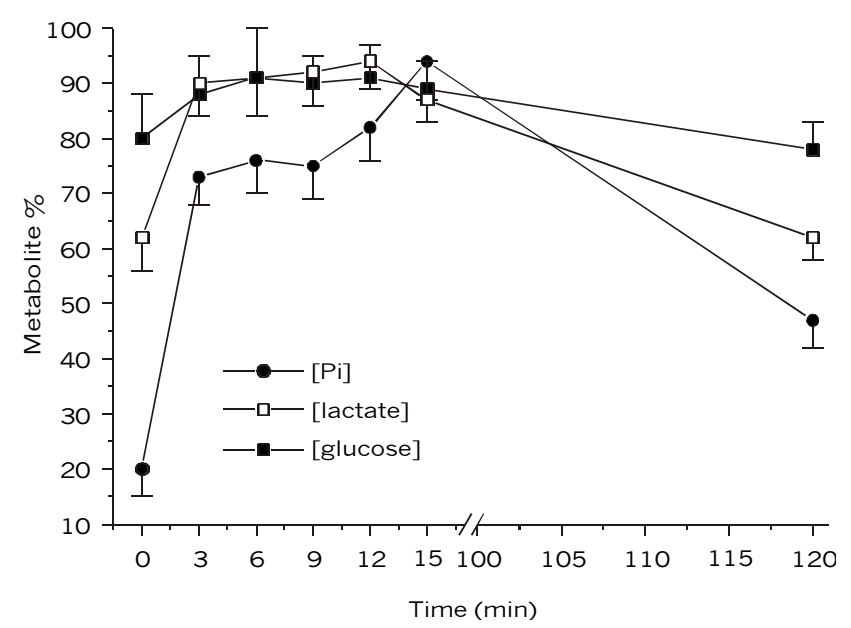

Fig. 1 - Changes of plasma metabolites expressed as relative ratio (actual value $\times$ maximum value $\left.{ }^{-1}\right) \times 100$, during sustained swimming of Salminus maxillosus for 15 minutes. Metabolite ratio at zero time is the mean $\pm \mathrm{SD}$ of pre-control and control.

Acknowledgements - The authors thank Dr. Raul H. Piedrahita of the Univ. of California for advice and suggestions, and Alexandre E. Altran for logistical support. This paper was adapted from work submitted by Jomuna V. Choudhuri, in partial fulfillment of requirements for a degree in Biology from the Federal University of Sao Carlos, SP. The research was funded by the Conselho Nacional de Desenvolvimento Científico e Tecnológico (CNPq).

\section{REFERENCES}

BIDINOTTO, P. M., MORAES, G. \& SOUZA, R. H. S., 1997, Hepatic glycogen and glucose in eight tropical fresh water teleost fish: A procedure for field determinations of microsamples. Bol. Tec. do CEPTA, 10: 53-60.

CAMERON, J. N. \& CECH, J. J., 1990, Lactate kinetics in exercised channel catfish, Ictalurus punctatus. Physiol. Zool., 63(5): 909-920.

COPLEY, N. G., 1941, Alloxan and ninhydrin test. Analyst., 66: 492-493.

DUBOIS, M., GILLES, K. A., HAMILTON, J. K., REBERS, P. A. \& SMITH, F., 1956, Colorimetric methods for determination of sugars and related substances. Anal. Chem., 28: 350-358.

FINDLAY, R. H., KING, G. M. \& WATLING, L. 1989, Efficacy of phospholipid analysis in determining microbial biomass in sediments. Appl. Environm. Microbiol., 55(11): 2888-2893.

GODOY, M. P., 1987, Rescue the dourado in the Paraná, Paraguai, Uruguai and Plate River Basin, pp. 311-313. In: D. W. Reed (ed.), Spirit of interprise: 1987 Rolex Awards. Van Nostrand Reinhold, Berkshire.

HARROWER, J. R. \& BROWN, C. H., 1972, Blood lactic acid. A micromethod adapted to field collection of microliter samples. J. Appl. Physiol., 32(5): 224-228.

HAUX, C., SJOBECK, M. \& LARSSON, A., 1985, Physiological stress responses in a wild fish population of perch (Perca fluviatilis) after capture and during subsequent recovery.

Braz. J. Biol., 64(3B): 655-660, 2004
Mar. Environ. Res., 15: 77-95

HOCHACHKA, P. W., 1985, Fuels and pathways as designed systems for support of muscle work. J. Exp. Biol., 115: 149-164.

LU, G. D., 1939, The metabolism of pyruvic acid in normal and vitamin B-deficient state. I. A rapid specific and sensitive method for the estimation of blood pyruvate. Biochem. J., 33: 249-254.

MILLIGAN, C. L. \& GIRARD, S. S., 1993, Lactate metabolism in rainbow trout. J. Exp. Biol., 180: 175193.

SCHWALME, K. \& MACKAY, W. C., 1985a, The influence of exercise-handling stress on blood lactate, acid-base, and plasma glucose status of northern pike (Esox lucius L). Can J. Zool., 63: 1125-1129.

SCHWALME, K. \& MACKAY, W. C., 1985b, The influence of angling-induced exercise on the carbohydrate metabolism of the northern pike (Esox lucius L). J. Comp. Physiol. B, 156: $67-75$

SCHWALME, K. \& MACKAY, W. C., 1991, Mechanisms that elevate glucose concentration of muscle and liver in yellow perch (Perca flavescen Mitchill) after exercise-handling stress. Can. J. Zool., 69: 456-461.

WARDLE, C. S., 1978, Non-release of lactic acid from anaerobic swimming muscle of plaice Pleuronectes platessa L.: a stress reaction. J. Exp. Biol., 77: 141-155.

WARING, C. P., STAGG, R. M. \& POWTON, M. G., 1992, The effects of handling on flounder (Platichthys flesus L.) and Atlantic salmon (Salmo salar L.). J. Fish Biol., 48: 161-173.

WELLS, R. M. G., MCINTYRE, R. H., MORGAN, A. K. \& DAVIES, P. S., 1986, Physiological stress response in big gamefish capture: observation in plasma chemistry and blood factors. Comp. Bichem. Physiol., 84(A): 565-571.

WOOD, C. M. \& PERRY, S. F., 1985, Comparative physiology and biochemistry: current topics and trends. pp. 1-22.

WYDOSKI, R. S., WEDEMEYER, G. A. \& NELSON, N. C., 1976, Physiological response to hooking stress in hatchery and wild rainbow trout (Salmo gardneri). Trans. Am. Fish. Soc., 105: 601-606. 